\title{
Genomic conservation of cattle microsatellite loci in wild gaur (Bos gaurus) and current genetic status of this species in Vietnam Trung Thanh Nguyen ${ }^{\dagger 1}$, Sem Genini ${ }^{\dagger 2}$, Linh Chi Bui ${ }^{1}$, Peter Voegeli ${ }^{3}$, Gerald Stranzinger ${ }^{3}$, Jean-Paul Renard ${ }^{4}$, Jean-Charles Maillard ${ }^{5}$ and Bui Xuan Nguyen*1
}

Address: ${ }^{1}$ Vietnamese Academy of Sciences and Technology, Hanoi, Vietnam, ${ }^{2}$ Parco Tecnologico Padano (PTP), CERSA, Via Einstein, 26900 Lodi, Italy, ${ }^{3}$ Institute of Animal Sciences, Breeding Biology, Swiss Federal Institute of Technology, 8092 Zurich, Switzerland, ${ }^{4}$ UMR Biologie du Développement et de la Reproduction. INRA, 78350 Jouy en Josas, France and ${ }^{5}$ Centre de Coopération Internationale en Recherche Agronomique pour le Développement (CIRAD), Montpellier, France

Email: Trung Thanh Nguyen - nguyentt@mnhn.fr; Sem Genini - sem.genini@tecnoparco.org; Linh Chi Bui - linh-chi.bui@univ-paris5.fr; Peter Voegeli - peter.voegeli@inw.agrl.ethz.ch; Gerald Stranzinger - irmtraut.gerald@ggaweb.ch; Jean-Paul Renard - jeanpaul.renard@jouy.inra.fr; Jean-Charles Maillard - jean-charles.maillard@cirad.fr; Bui Xuan Nguyen* - saola@netnam.vn

* Corresponding author †Equal contributors

Published: 6 November 2007

BMC Genetics 2007, 8:77 doi:10.1/86/147/-2156-8-77
Received: 28 May 2007

Accepted: 6 November 2007

This article is available from: http://www.biomedcentral.com/I47I-2/56/8/77

(c) 2007 Nguyen et al; licensee BioMed Central Ltd.

This is an Open Access article distributed under the terms of the Creative Commons Attribution License (http://creativecommons.org/licenses/by/2.0), which permits unrestricted use, distribution, and reproduction in any medium, provided the original work is properly cited.

\begin{abstract}
Background: The wild gaur (Bos gaurus) is an endangered wild cattle species. In Vietnam, the total number of wild gaurs is estimated at a maximum of 500 individuals. Inbreeding and genetic drift are current relevant threats to this small population size. Therefore, information about the genetic status of the Vietnamese wild gaur population is essential to develop strategies for conservation and effective long-term management for this species. In the present study, we performed cross-species amplification of 130 bovine microsatellite markers, in order to evaluate the applicability and conservation of cattle microsatellite loci in the wild gaur genome. The genetic diversity of Vietnamese wild gaur was also investigated, based on data collected from the 1 I7 successfully amplified loci.

Results: One hundred-thirty cattle microsatellite markers were tested on a panel of II animals. Efficient amplifications were observed for 117 markers (90\%) with a total of 264 alleles, and of these, 68 (58.1\%) gave polymorphic band patterns. The number of alleles per locus among the polymorphic markers ranged from two to six. Thirteen loci (BMI3I4, BM2304, BM60I7, BMC2228, BMS332, BMS9II, CSSM023, ETHI23, HAUTI4, HELII, HEL5, ILSTSO05 and INRA 189) distributed on nine different cattle chromosomes failed to amplify wild gaur genomic DNA. Three cattle $Y$ chromosome specific microsatellite markers (INRA I24, INRA I 26 and BM86I) were also highly specific in wild gaur, only displaying an amplification product in the males. Genotype data collected from the 117 successfully amplified microsatellites were used to assess the genetic diversity of this species in Vietnam. Polymorphic Information Content (PIC) values varied between 0.083 and 0.767 with a mean of 0.252 while observed heterozygosities $\left(H_{0}\right)$ ranged from 0.09 I to 0.909 (mean of 0.269 ). Nei's unbiased mean heterozygosity and the mean allele number across loci were 0.298 and 2.2, respectively.

Conclusion: Extensive conservation of cattle microsatellite loci in the wild gaur genome, as shown by our results, indicated a high applicability of bovine microsatellites for genetic characterization and population genetic studies of this species. Moreover, the low genetic diversity observed in Vietnamese wild gaur further underlines the necessity of specific strategies and appropriate management plans to preserve this endangered species from extinction.
\end{abstract}




\section{Background}

The wild gaur, also known as the Indian bison or seladang, is a member of the subfamily Bovinae and is currently classified among endangered species and listed as vulnerable by International Union for Conservation of Nature and Natural Resources [1]. According to the Asian Wild Cattle Conservation Assessment and Management Plan (CAMP - [2]), three wild subspecies are generally recognized, including Bos gaurus laosiensis (Myanmar to China), Bos gaurus hubbacki (Thailand and Malaysia) and Bos gaurus gaurus (India and Nepal). Recently, the species name Bos gaurus was suggested for wild gaur instead of Bibos gauris or Bos frontalis by the International Commission on Zoological Nomenclature [3]; this name is currently used.

The gaur is one of the most impressive and largest of the wild cattle. A typical adult wild gaur bull may measure up to two meters at the shoulders and $900 \mathrm{~kg}$ in weight [4]. Gaurs are gregarious animals that live in hilly terrains below an altitude of 1,800 meters in herds ranging from 6 to 40 individuals. The distribution of wild gaur includes areas of southern and south-eastern Asia, from India to peninsular Malaysia, occurring in India, Nepal, Bhutan, Bangladesh, Myanmar, Thailand, China, Laos, Cambodia, Vietnam and Malaysia [5,6]. In India, wild gaurs have been probably domesticated about 2500 years ago [7], mainly for work and meat [8]. Domesticated gaurs are referred to as "gayal" or "mithan" (Bos frontalis) and are completely interfertile with their wild relatives [9], which display a karyotype of $2 n=58$ [10]. Furthermore, herders breed mithans or cross them with cattle to obtain offspring with enhanced production and performance, however usually only F1 females are fertile and can be used for further breeding purposes.

The global population of wild gaur ranges from 13,000 to 30,000 with a population of mature individuals between 5,200 and 18,000 . In the last decades, the number of wild gaurs decreased dramatically due to the loss of suitable habitat (in favour of agriculture and its domestic counterpart), hunting or hybridization with domestic cattle [11]. The latter threat also caused the transmission and outbreak of various devastating diseases, such as foot-andmouth, rinderpest and anthrax [12]. In Vietnam, the total number of wild gaurs is estimated at a maximum of 500 individuals of which $10 \%$ distributed in the Cat Tien National Park, localized close to the Ho Chi Minh City in the south of the country. During 1991-1995, 120 wild gaurs were reported to be killed (more than one generation [1]). Thus, information about the current genetic status of the Vietnamese wild gaur population is important and necessary to develop strategies for conservation and effective long-term management for this species.
Successful amplification and extensive conservation of cattle microsatellite sequences in several species of Bovidae and Cervidae families have been documented in numerous works $[13,14]$, thus allowing possible population genetic studies on related Bovidae species for which microsatellites have not been developed [15-18]. Furthermore, cross-species amplification was also applied to the study of population variations in geographically isolated or endangered species $[19,20]$. These studies suggest that a characterization of wild gaur, as a member of the subfamily Bovinae, with bovine microsatellite markers is highly pertinent and suitable.

Previous genetic studies were carried out on gaur [21,22], however they were limited to a domesticated group of Bos frontalis and only a low number of cattle microsatellites were analyzed. Therefore, the questions about the conservation of cattle microsatellite DNA sequences, as well as the applicability of these markers for population genetic studies in Bos gaurus remain open.

The principal aims of this study were (1) to evaluate the applicability and conservation of cattle microsatellite DNA sequences in the wild gaur genome and (2) to estimate the current genetic status of this species in Vietnam.

\section{Results and discussion}

One hundred-thirty cattle microsatellite markers were tested for amplification of genomic DNA from a panel of 11 wild gaurs. Three Brown Swiss cattles (Bos taurus) were used as positive control. Although some amplification failures were observed, $90 \%$ of the microsatellites from cattle could be successfully amplified by PCR on gaur genomic DNA, of which 68 markers (58.1\%) were polymorphic. A total of 264 alleles were detected across the 117 amplified loci with the number of alleles ranging from one to six (Table 1) with a mean of 2.2 alleles per locus. Thirteen microsatellites (10\%) distributed on cattle chromosomes 8 (BM2304), 10 (ILSTS005), 18 (HAUT14), 21 (HEL5), 24 (CSSM023), 26 (BM1314, BMS332 and HEL11), 29 (BMC2228), X (BM6017, BMS911 and ETH123) and Y (INRA189), respectively, failed to amplify in wild gaur. Notably, the non-amplification of locus ILSTS005 indicated the absence of this sequence in both wild gaur and mithan [22]. As expected, all the microsatellite markers could be successfully amplified in the positive control samples (Bos taurus), with $92 \%$ of them being polymorphic.

The applicability of bovine microsatellite markers for genetic studies in several Bovidae species has been reported in different studies and demonstrated extensive genomic conservation of cattle DNA microsatellite sequences during evolution. However, this conservation varies consistently within the Bovidae subfamilies and 
Table I: Characterisation of I 30 bovine microsatellites tested on a panel of I I wild gaurs

\begin{tabular}{|c|c|c|c|c|c|c|}
\hline Marker & Chromosome no. in cattle & Allele size range (bp) & Number of alleles & $H_{E}$ & $H_{0}$ & $P I C$ \\
\hline AGLAI7 & 1 & $2|7-22|$ & 3 & 0.385 & 0.273 & 0.326 \\
\hline AGLA293 & 5 & $231-231$ & I & - & - & - \\
\hline BLI029 & 14 & $15 \mid-155$ & 2 & 0.091 & 0.091 & 0.083 \\
\hline BLI038 & 6 & $109-109$ & I & - & - & - \\
\hline BLI040 & 26 & $96-108$ & 3 & 0.255 & 0.273 & 0.228 \\
\hline BLI043 & 7 & $100-104$ & 3 & 0.177 & 0.182 & 0.163 \\
\hline BLI07I & 13 & $179-195$ & 4 & 0.680 & 0.636 & 0.594 \\
\hline BLI095 & 15 & $164-174$ & 3 & 0.385 & 0.455 & 0.326 \\
\hline BL25 & 28 & $171-185$ & 2 & 0.247 & 0.273 & 0.208 \\
\hline$B M / 3 / 4^{*}$ & 26 & - & - & - & - & - \\
\hline$B M / 8 / 8$ & 23 & $264-264$ & I & - & - & - \\
\hline$B M / 824$ & 1 & $187-187$ & 1 & - & - & - \\
\hline$B M / 862$ & 17 & $201-213$ & 3 & 0.567 & 0.727 & 0.463 \\
\hline$B M / 88$ & 26 & $108-108$ & I & - & - & - \\
\hline BM203 & 27 & $2|1-2| 3$ & 2 & 0.312 & 0.182 & 0.253 \\
\hline$B M 21 / 3$ & 2 & $129-129$ & I & - & - & - \\
\hline BM2304* & 8 & - & - & - & - & - \\
\hline BM3020 & 3 & $159-159$ & I & - & - & - \\
\hline BM4005 & 25 & $107-107$ & I & - & - & - \\
\hline BM4602 & 29 & $128-130$ & 2 & 0.519 & - & 0.373 \\
\hline$B M 462 I$ & 6 & $|3|-|3|$ & I & - & - & - \\
\hline BM60/7* & $x$ & - & - & - & - & - \\
\hline BM6425 & 14 & $167-195$ & 6 & 0.823 & 0.818 & $0.75 I$ \\
\hline$B M 6438$ & 1 & $256-256$ & I & - & - & - \\
\hline BM6465 & 3 & $122-122$ & 1 & - & - & - \\
\hline$B M 8 / 39$ & I & $110-116$ & 3 & 0.394 & 0.273 & 0.344 \\
\hline$B M 8 / 5 I$ & 18 & $|57-16|$ & 3 & 0.589 & 0.545 & 0.476 \\
\hline BM86I & $Y$ & $135-135$ & 1 & - & - & - \\
\hline BM875 & 10 & $107-119$ & 2 & 0.519 & 0.364 & 0.373 \\
\hline BMCI4IO & 4 & $215-219$ & 3 & 0.593 & 0.636 & 0.504 \\
\hline BMC2228* & 29 & - & - & - & - & - \\
\hline BMC6020 & 28 & $177-177$ & I & - & - & - \\
\hline BMC602I & $x$ & $|4|-|4|$ & I & - & - & - \\
\hline BMSI074 & 4 & $157-157$ & 1 & - & - & - \\
\hline BMSII 20 & 20 & $123-137$ & 6 & 0.835 & 0.909 & 0.767 \\
\hline BMSI I 28 & 20 & $80-82$ & 2 & 0.091 & 0.091 & 0.083 \\
\hline BMSI 244 & 29 & $103-105$ & 2 & 0.173 & 0.182 & 0.152 \\
\hline$B M S I 247$ & 7 & ||$|-| 2 \mid$ & 3 & 0.537 & 0.364 & 0.444 \\
\hline BMSI 282 & 20 & $15 \mid-165$ & 4 & 0.333 & 0.273 & 0.302 \\
\hline$B M S / 322$ & 18 & $|17-12|$ & 3 & 0.498 & 0.091 & 0.419 \\
\hline BMSI 353 & 25 & $95-103$ & 2 & 0.368 & 0.091 & 0.290 \\
\hline BMSI355 & 18 & $154-160$ & 4 & 0.697 & 0.818 & 0.607 \\
\hline BMSI $6 / 6$ & $x$ & $65-65$ & I & - & - & - \\
\hline BMSI $7 / 4$ & 28 & $120-122$ & 2 & 0.416 & 0.545 & 0.318 \\
\hline BMSI 825 & 17 & $191-191$ & 1 & - & - & - \\
\hline BMSI 857 & 29 & $155-165$ & 4 & 0.675 & 0.545 & 0.575 \\
\hline BMS/926 & 24 & $132-136$ & 3 & 0.394 & 0.091 & 0.344 \\
\hline BMSI928 & 1 & $|4|-|6|$ & 4 & 0.576 & 0.636 & $0.5 \mathrm{II}$ \\
\hline BMS 1948 & 29 & $93-93$ & i & - & - & - \\
\hline BMSI979 & 7 & $95-99$ & 3 & 0.498 & 0.636 & 0.419 \\
\hline$B M S 22 / 3$ & 18 & $112-120$ & 2 & 0.524 & 0.455 & 0.375 \\
\hline BMS2252 & 12 & | 58-| 64 & 4 & 0.697 & 0.455 & 0.604 \\
\hline BMS2270 & 24 & $57-63$ & 2 & 0.485 & 0.545 & 0.356 \\
\hline BMS2526 & 24 & $135-159$ & 4 & 0.762 & 0.636 & 0.678 \\
\hline BMS2639 & 18 & $160-160$ & $i$ & - & - & - \\
\hline BMS3024 & 24 & $\mid 42-142$ & 1 & - & - & - \\
\hline BMS332* & 26 & - & - & - & - & - \\
\hline BMS40I5 & I & |44-| 52 & 4 & 0.688 & 0.636 & 0.606 \\
\hline BMS424B & 11 & $256-258$ & 2 & 0.091 & 0.091 & 0.083 \\
\hline
\end{tabular}


Table I: Characterisation of I 30 bovine microsatellites tested on a panel of I I wild gaurs (Continued)

\begin{tabular}{|c|c|c|c|c|c|c|}
\hline BMS522 & 7 & $134-134$ & $\mathrm{~T}$ & - & - & - \\
\hline BMS574 & I & $|3|-|3|$ & I & - & - & - \\
\hline BMS63I & $x$ & $146-146$ & I & - & - & - \\
\hline BMS650 & 19 & $|4|-|4|$ & i & - & - & - \\
\hline BMS672 & 22 & $\mid 43-143$ & I & - & - & - \\
\hline BMS7I I & 1 & $102-102$ & 1 & - & - & - \\
\hline BMS745 & 19 & $109-109$ & I & - & - & - \\
\hline BMS779 & 4 & $191-195$ & 2 & 0.312 & 0.364 & 0.253 \\
\hline BMS9II* & $x$ & - & - & - & - & - \\
\hline BR4206 & 18 & $110-110$ & I & - & - & - \\
\hline BR4406 & 18 & $114-114$ & 1 & - & - & - \\
\hline CSRM60 & 10 & $86-114$ & 2 & 0.368 & 0.273 & 0.290 \\
\hline CSSM023* & 24 & - & - & - & - & - \\
\hline CSSM66 & 14 & $182-202$ & 3 & 0.593 & 0.727 & 0.504 \\
\hline ETHIO & 5 & $207-213$ & 3 & 0.450 & 0.455 & 0.385 \\
\hline ETHII & 16 & $204-212$ & 4 & 0.688 & 0.636 & 0.593 \\
\hline ETHILI & 2 & $182-210$ & 3 & 0.498 & 0.455 & 0.419 \\
\hline ETHI23* & $x$ & - & - & - & - & - \\
\hline ETHI52 & 5 & $198-198$ & I & - & - & - \\
\hline ETHI 85 & 17 & $219-219$ & i & - & - & - \\
\hline ETH225 & 9 & |45-| 59 & 3 & 0.636 & 0.636 & 0.524 \\
\hline ЕTHЗ & 19 & $|27-| 3 \mid$ & 3 & 0.654 & 0.545 & 0.553 \\
\hline HAUTI $4^{*}$ & 18 & - & - & - & - & - \\
\hline HAUT24 & 22 & $120-120$ & I & - & - & - \\
\hline HAUT27 & 26 & $145-145$ & 1 & - & - & - \\
\hline HELI & 15 & $108-120$ & 3 & 0.628 & 0.636 & 0.519 \\
\hline HELII* & 26 & - & - & - & - & - \\
\hline HELI 3 & 11 & $193-203$ & 3 & 0.325 & 0.364 & 0.282 \\
\hline HEL5* & 21 & - & - & - & - & - \\
\hline HEL9 & 8 & $146-152$ & 4 & 0.610 & 0.545 & 0.533 \\
\hline IDVGA59 & 26 & $250-254$ & 3 & 0.437 & 0.364 & 0.360 \\
\hline IDVGA90 & 7 & $194-194$ & 1 & - & - & - \\
\hline ILSTSO05* & 10 & - & - & - & - & - \\
\hline ILSTSO06 & 7 & $275-281$ & 2 & 0.173 & & 0.152 \\
\hline ILSTSOI 5 & 29 & $265-265$ & I & - & - & - \\
\hline ILSTSOI 7 & $x$ & $117-117$ & I & - & - & - \\
\hline ILSTSO2 I & 18 & $116-116$ & 1 & - & - & - \\
\hline ILSTSIO2 & 25 & $|46-| 46$ & I & - & - & - \\
\hline INRA005 & 12 & $|35-| 4 \mid$ & 4 & 0.697 & 0.818 & 0.600 \\
\hline INRA023 & 3 & $207-217$ & 4 & 0.710 & 0.636 & 0.623 \\
\hline INRA032 & II & $|69-18|$ & 5 & 0.753 & 0.727 & 0.674 \\
\hline INRA035 & 16 & $108-108$ & 1 & - & - & - \\
\hline INRA037 & 10 & $126-132$ & 4 & 0.727 & 0.636 & 0.637 \\
\hline INRA063 & 18 & $\mid 73-187$ & 5 & 0.758 & 0.636 & 0.675 \\
\hline INRA08I & 26 & $145-153$ & 3 & 0.567 & 0.545 & 0.463 \\
\hline INRA I I 7 & I & $91-97$ & 2 & 0.173 & 0.182 & 0.152 \\
\hline INRAIII & 18 & $114-136$ & 4 & 0.710 & 0.545 & 0.615 \\
\hline INRA I 24 & $Y$ & $132-132$ & i & - & - & - \\
\hline INRA I 26 & $Y$ & $182-182$ & I & - & - & - \\
\hline INRA / 33 & 6 & $22|-23|$ & 3 & 0.437 & 0.364 & 0.360 \\
\hline INRA I 83 & 27 & $117-117$ & 1 & - & - & - \\
\hline INRA I 89* & $Y$ & - & - & - & - & - \\
\hline MB054 & 18 & $123-123$ & 1 & - & - & - \\
\hline MB085 & 15 & $198-202$ & 3 & 0.593 & 0.455 & 0.505 \\
\hline $\mathrm{MHClI}$ & 23 & $213-225$ & 4 & 0.723 & 0.636 & 0.633 \\
\hline$M M / 2 E 6$ & 9 & $108-108$ & i & - & - & - \\
\hline RM026 & 26 & $8 I-8 I$ & I & - & - & - \\
\hline RM372 & 8 & $128-134$ & 3 & 0.450 & 0.364 & 0.385 \\
\hline SPSII 5 & 15 & $253-253$ & 1 & - & - & - \\
\hline TEXANIO & 18 & $|45-| 5 \mid$ & 4 & 0.706 & 0.818 & 0.613 \\
\hline TGLA / 22 & 21 & $166-168$ & 2 & 0.455 & 0.455 & 0.340 \\
\hline TGLAI 26 & 20 & $121-125$ & 3 & 0.498 & 0.091 & 0.419 \\
\hline TGLAI79 & 27 & $89-103$ & 3 & 0.697 & 0.636 & 0.591 \\
\hline
\end{tabular}


Table I: Characterisation of I 30 bovine microsatellites tested on a panel of I I wild gaurs (Continued)

\begin{tabular}{|c|c|c|c|c|c|c|}
\hline TGLA227 & 18 & $72-84$ & 3 & 0.584 & 0.455 & 0.490 \\
\hline TGLA23 & 13 & $100-104$ & 3 & 0.567 & 0.818 & 0.436 \\
\hline TGLA49 & I & $115-117$ & 2 & 0.247 & 0.273 & 0.208 \\
\hline TGLA53 & 16 & $|5|-\mid 75$ & 5 & 0.701 & 0.727 & 0.606 \\
\hline TGLA73 & 9 & $116-126$ & 4 & 0.749 & 0.727 & 0.663 \\
\hline UWCA25 & 13 & $102-102$ & I & - & - & - \\
\hline$X B M I I$ & $x$ & $182-182$ & I & - & - & - \\
\hline XBM7 & $x$ & $174-174$ & I & - & - & - \\
\hline
\end{tabular}

$*=$ markers not amplified

$H_{E}=$ expected heterozygosity

$H_{0}=$ observed heterozygosity

PIC = polymorphism Information Content

The 28 microsatellites with PIC value $>0.5$ are bold-faced. Information concerning the bovine microsatellite markers used can be acquired from internet sites [32-34].

species (Table 2), as one can also expect by phylogenetic analyses. Additionally, percentage variations of conserved and polymorphic loci also depend on experimental conditions; specifically the number and the identity of the specific set of markers, as well as the number of animals tested play essential roles. This explains the variable levels of marker conservation in water buffalo, goat and sheep obtained from different studies (see Table 2 for references). The average conservation of cattle microsatellite loci across Caprinae species was generally lower than for Bovinae; in fact goat [23] and sheep [13] showed the lowest among all Bovidae. However, these results do not completely account for the experimental differences discussed above, which might influence the finding. With the same set of cattle microsatellites used in this study, our data suggest that Bos indicus is more closely related to Bos taurus than either Bos gaurus, Poephagus grunniens or Pseudoryx nghetinhensis (Table 2 and references therein). Within the
Bovini, a close relationship between wild gaur and banteng (Bos javanicus) could be expected, as $90 \%$ and $94 \%$ of cattle microsatellites were conserved in their genomes, respectively (Table 2). These results were in line with recent taxonomy classifications of Bovidae based on molecular phylogenetic analyses [24,25] and AFLP data [26]. Additionally, genomic conservation of cattle microsatellites has been tested on Cervidae, whereas $73.7 \%$ and $74.1 \%$ of bovine markers could be successfully amplified in sika deer (Cervus nippon) and red deer (Cervus elaphus), respectively [14]. Within species of Bos, wild gaur showed the lowest proportion of polymorphic markers (Table 2). This finding was in agreement and is possibly related to the small effective population size of Vietnamese wild gaurs, compared to other bovid species. The average allele sizes of most successful amplified markers in wild gaur were smaller compared to those obtained in cattle. This

Table 2: Genomic conservation of cattle microsatellite loci within the Bovidae and Cervidae families using cross species amplification

\begin{tabular}{|c|c|c|c|c|}
\hline Taxon & Species - common name & Conserved loci & Polymorphic loci & References \\
\hline \multicolumn{5}{|l|}{ Bovidae, Bovinae } \\
\hline \multirow[t]{4}{*}{ Bovini, Bovina } & Bos gaurus - Wild gaur & $90 \%$ & $58.1 \%$ & this study \\
\hline & Bos indicus - Zebu & $97.6 \%$ & $87.3 \%$ & Nguyen - person. comm \\
\hline & Bos javanicus - Banteng & $94 \%$ & $75 \%$ & Hishida et al. [40] \\
\hline & Poephagus grunniens - Yak & $94.6 \%$ & $94.3 \%$ & Nguyen et al. [18] \\
\hline \multirow[t]{4}{*}{ Bovini, Bubalina } & Bubalus bubalis - Water buffalo & $70 \%$ & $82 \%$ & Moore et al. [19] \\
\hline & & $75 \%$ & $56 \%$ & Navani et al. [16] \\
\hline & & $85 \%$ & $57 \%$ & Hishida et al. [40] \\
\hline & Syncerus caffer - African buffalo & $83 \%$ & $90 \%$ & van Hooft et al. [15] \\
\hline Bovini, Pseudoryina & Pseudoryx nghetinhensis - Saola & $96.8 \%$ & $59.3 \%$ & Nguyen et al. [20] \\
\hline \multicolumn{5}{|l|}{ Bovidae, Caprinae } \\
\hline \multirow[t]{4}{*}{ Caprini } & Capra hircus - Goat & $57 \%$ & $33 \%$ & Kemp et al. [23] \\
\hline & & $79.4 \%$ & $81.5 \%$ & Kim et al. [I7] \\
\hline & Ovis aries - Sheep & $58 \%$ & $67 \%$ & de Gortari et al. [13] \\
\hline & & $73.4 \%$ & $42.5 \%$ & Slate et al. [14] \\
\hline Naemorhedini & Naemorhedus caudatus - Korean goral & $85.3 \%$ & $55.2 \%$ & Kim et al. [I7] \\
\hline \multicolumn{5}{|l|}{ Cervidae, Cervinae } \\
\hline \multirow[t]{2}{*}{ Cervus } & Cervus elaphus - Red deer & $74.1 \%$ & $55.8 \%$ & Slate et al. [14] \\
\hline & Cervus nippon - Sika deer & $73.7 \%$ & $37.3 \%$ & Slate et al. [14] \\
\hline
\end{tabular}


was expected [27] and in agreement with previous studies using cross-species amplification [15,17].

The conservation of DNA sequences flanking microsatellites in the sex chromosomes among cattle and wild gaur was evaluated by testing the amplification of nine microsatellite loci, which mapped to BTAX (BM6017, BMC6021, BMS1616, BMS631, BMS911, ETH123, ILSTS017, XBM11 and XBM7) and four additional loci (INRA124, INRA126, INRA189 and BM861), which mapped to BTAY. All these sex-specific microsatellite markers were monomorphic. The loci BM6017, BMS911, ETH123 and INRA189 failed to amplify sex-chromosome specific DNA in wild gaur. Recently, it has also been reported that locus $B M 6017$ could not be amplified in yaks [18]. This could be attributed to the absence of homologous sequences in both species. Moreover, studies demonstrated that BM861 and INRA126 successfully amplified from both sexes in yak $[18,21]$ and saola (Pseudoryx nghetinhensis - [20]), suggesting that they are not Yspecific. These findings indicated that yak and saola $\mathrm{X}$ chromosome retained a homologous segment of the $\mathrm{Y}$ chromosome, which contains both BM861 and INRA126 microsatellite markers. Contrary to these studies, we could amplify INRA124, INRA126 and BM861 only in male wild gaurs, indicating that they are $\mathrm{Y}$ specific markers in this species. Hanotte et al. [28] also tried to amplify locus INRA124 in two males of mithan but failed to obtain an amplification product. Even though we could not find any polymorphism for INRA124, INRA126 and $B M 861$, these three microsatellites were polymorphic in several bovid species, including domestic cattle, bison, mithan, swamp buffalo and yak $[21,28]$. This may be due to the relative small number (7) of male wild gaurs analyzed, which may have limited the informative content of this marker. In addition, the significant difference in allele size of locus $B M 861$ between wild (135 bp) and domestic gaur (mithan, 150-156 bp -[21]) might be explained by the introgressive hybridisation of mithan, leading to the loss of the $135 \mathrm{bp}$ allele from its wild ancestor.

Finally, genotype data collected from the 117 successfully amplified microsatellites were used for genetic studies of the Vietnamese wild gaur population. The expected heterozygosity value per locus across the population varied between 0.091 (BL1029, BMS1128 and BMS424B) and 0.835 (BMS1120) (Table 1). Accordingly, markers BL1029, BMS1128 and BMS424B showed the lowest PIC value (0.083), whereas BMS1120 had the highest $(0.767)$ with a mean of 0.252 . In addition, the observed heterozygosities $\left(H_{o}\right)$ ranged from 0.091 to 0.909 . Twenty-eight microsatellites (BL1071, BM6425, BMC1410, BMS1120, BMS1355, BMS1857, BMS1928, BMS2252, BMS2526, BMS4015, CSSM66, ETH11, ETH225, ETH3, HEL1, HEL9, INRA005, INRA023， INRA032, INRA037, INRA063,
INRA121, MB085, MHCII, TEXAN10, TGLA179, TGLA53 and TGLA73; bold-faced in Table 1) showed good level of informativeness, having a PIC value higher than the threshold of 0.5 that is considered the value from which markers begin to be informative and therefore they would be the most suitable for diversity studies. Among these 28 most informative microsatellites, ten (CSSM66, ETH225, ETH3, HEL1, HEL9, INRA023, INRA032, INRA037, INRA063 and TGLA53) are also in the FAO standard panel of 30 microsatellites for diversity studies, allowing the study of introgression.

The average observed heterozygosity value $\left(H_{o}=0.269\right)$ was lower than the average expected heterozygosity (Nei's unbiased mean heterozygosity; $\left.H_{E}=0.298\right)$ and this difference was statistically significant. Eleven (BM4602, BMS1322, BMS1353, BMS1926, ILSTS006, INRA037, INRA063, MHCII, TEXAN10, TGLA126 and TGLA73) out of 117 loci (9.4\%) showed significant deviation from the Hardy-Weinberg equilibrium at $p<0.05$. Over all loci, departure from Hardy Weinberg equilibrium was statistically highly significant $(p<0.001)$, reflecting the deviation in the direction of heterozygote deficit. These results indicate a frequent portion of homozygous individuals in the Vietnamese wild gaur population, resulting in an inbreeding coefficient value $\left[\mathrm{F}=\left(H_{E}-H_{o}\right) / H_{E}\right]$ of 0.10 . Deviations from Hardy-Weinberg equilibrium of the population studied might be the results of inbreeding, but could also have been caused by the presence of nonamplifying (null) alleles, which could have contributed to the heterozygote deficiencies. In addition, the low average heterozygosity of wild gaurs may also be the consequence of the use of cattle derived microsatellite markers, which are expected to perform less in related species, having a higher fraction of null alleles and being less polymorphic.

\section{Conclusion}

The degree of polymorphism in the high number of microsatellite markers tested provides important information about the current genetic status of Vietnamese wild gaur. Its small population size would be dramatically adversely affected by high inbreeding and genetic drift. Therefore, the use of cattle microsatellites is adequate and recommended for further population genetic analyses, aimed to develop effective long-term conservation plans and strategies for this threatened species in Asia, especially in Vietnam. The reported low level of genetic diversity in wild gaur possibly reflects a bottleneck effect following the dramatic population reduction that occurred in this country during 1991-1995.

\section{Methods \\ Sample collection}

Eleven wild gaur samples ( 7 males and 4 females) were randomly collected in South Vietnam from the Chu Mom 
Ray Nature Reserve, Kon Tum province and Thao Cam Vien (Zoo and Botanical Garden), Ho Chi Minh City. Genomic DNA was extracted from tissue samples, fibroblast cells and bone fragments following standard methods $[29,30]$ with minor modifications. DNA from three Brown Swiss cattles (Bos taurus) was obtained from EDTAanticoagulated whole blood [31] and used as positive control.

\section{Microsatellite analysis}

The same set of 130 bovine microsatellite markers analyzed by Nguyen et al. [18], excluded BPLP, and distributed across the entire cattle genome (Table 1) was tested for PCR amplification on wild gaur genomic DNA. The primer pairs, which show extensive polymorphism in cattle, were selected from internet sites [32-34]. The forward primer of each microsatellite was 5'-labeled with either FAM, JOE, TAMRA, HEX or TET fluorescent tag. PCR amplification was carried out, as described by Nguyen et al. [18], in a total reaction volume of $25 \mu \mathrm{l}$ containing 2030 ng DNA template, $1 \times$ PCR buffer $(10 \mathrm{mM}$ Tris- $\mathrm{HCl}, \mathrm{pH}$ 8.3, $50 \mathrm{mM} \mathrm{KCl}, 1.5 \mathrm{mM} \mathrm{MgCl} 2), 1.25 \mathrm{mM}$ of dNTP mix, $20 \mu \mathrm{M}$ of each primer and 1.25 units of Taq polymerase (SIGMA, Buchs, Switzerland). Samples were cycled in a PCR Express Machine (Thermocycler PCR Express, Hybaid) at $95^{\circ} \mathrm{C}$ for $5 \mathrm{~min}$, followed by 35 cycles of $95^{\circ} \mathrm{C}$ for $30 \mathrm{~s}, 52-60^{\circ} \mathrm{C}$ annealing temperature (depending on the microsatellite used) for $30 \mathrm{~s}$ and $72^{\circ} \mathrm{C}$ for $30 \mathrm{~s}$. The final elongation was at $72^{\circ} \mathrm{C}$ for $7 \mathrm{~min}$. Gel electrophoresis was performed with a $377 \mathrm{ABI}$ sequencer (Applied Biosystems, Rotkreuz, Switzerland) with Genescan-350 TAMRA or ROX as internal standards. Fragment sizing and analysis were done using ABI 672 Genescan software and Genotyper (version 2.1) software (Applied Biosystems).

\section{Statistical analysis}

Genotypes were assigned for each individual based on allele size data. Allele frequencies, expected heterozygosity $\left(H_{E}=1-\sum \mathrm{P}_{\mathrm{i}}{ }^{2}\right.$, where $\mathrm{P}_{\mathrm{i}}=$ frequency of allele $\left.\mathrm{i}\right)$, observed heterozygosity $\left(H_{o}\right)$ for all loci were computed using the Microsatellite Toolkit version 3.1 [35]. Genetic diversity was estimated according to Nei [36], using the average heterozygosity across all loci. Probability tests of Hardy-Weinberg equilibrium [37] based on Markov chain approaches (5000 iterations) were performed using the GENEPOP package version 3.4 [38]. The polymorphism information content (PIC) was calculated using the following formula:

$$
P I C=1-\sum_{i=1} P_{i}^{2}-\sum_{i=1} \sum_{j=i+1} P_{i}^{2} P_{j}^{2}
$$

where $P_{i}$ and $P_{j}$ are frequencies of $i^{\text {th }}$ and $j^{\text {th }}$ alleles [39].

\section{Authors' contributions}

TTN and SG prepared the DNA samples, performed the microsatellite analysis and drafted the manuscript. LCB carried out the statistical analysis and drafted the manuscript. PV, GS and JPR coordinated the analyses and helped in drafting the manuscript. JCM and BXN conceived and supervised the entire study. All authors read and approved the final manuscript.

\section{Acknowledgements}

We are grateful to Dr Do Tuoc, Forest Inventory and Planning Institute, Ministry of Forestry, Hanoi, Vietnam for the bone samples. We also thank Dr Uoc NT for sample collection and preparation. The gaur fibroblast cells were provided by the Laboratory of Embryotechnology, Vietnamese Academy of Science and Technology, Hanoi, Vietnam. This work was supported by BIODIVA-VAST project and the Swiss Federal Institute of Technology (ETH), Zurich.

\section{References}

I. IUCN Red List of Threatened Species [http://www.iucn redlist.org/]

2. Byers O, Hedges S, Seal US: Asian Wild Cattle Conservation Assessment and Management Plan workshop. Working Document. Apple Valley, MN, USA: IUCN/SSC Conservation Breeding Specialist Group; 1995.

3. ICZN: Opinion 2027 (Case 3010 ). Usage of 17 specific names based on wild species, which are pre-dated by or contemporary with those based on domestic animals (Lepidoptera, Osteichthyes, Mammalia): conserved. Bull Zool Nomencl 2003, 60:8I-84.

4. Prater PH: The Book of India Animals. Bombay, India: Bombay National History Society; 1980.

5. Ellerman JR, Morrison-Scott TCS: Checklist of Palaearctic and Indian Mammals 1758 to 1946. London: British Museum; I95I.

6. Corbet GB, Hill JE: The Mammals of the Indomalayan Region: a Systematic Review. Oxford: Oxford University Press; 1992.

7. Felius M: Cattle Breeds - An Encyclopedia. Doetinchem: Misset; 1995.

8. Simoons F): Gayal or mithan. In Evolution of Domesticated Animals Edited by: Mason IL. London: Longman; 1984:34-39.

9. Payne WJA: Domestication: a forward step in civilization. In Cattle Genetic Resources Edited by: Hickman CG. Amsterdam: Elsevier; | $991: 51-72$

10. Gallagher DS Jr, Womack JE: Chromosome conservation in the Bovidae. J Hered 1992, 83:287-298.

11. National Research Council: Little known Asian animals with a Promising Economic Future. Washington, D.C: National Academy Press; 1983.

12. Choudhury A: Distribution and conservation of the Gaur Bos gaurus in the Indian Subcontinent. Mam Rev 2002, 32:199-226.

13. de Gortari MJ, Freking BA, Kappes SM, Leymaster KA, Crawford AM, Stone RT, Beattie CW: Extensive genomic conservation of cattle microsatellite heterozygosity in sheep. Anim Genet 1997, 28:274-290.

14. Slate J, Coltman DW, Goodman SJ, MacLean I, Pemberton JM, Williams JL: Bovine microsatellite loci are highly conserved in red deer (Cervus elaphus), sika deer (Cervus nippon) and Soay sheep (Ovis aries). Anim Genet 1998, 29:307-3।5.

15. van Hooft WF, Hanotte O, Wenink PW, Groen AF, Sugimoto Y, Prins $\mathrm{HH}$, Teale A: Applicability of bovine microsatellite markers for population genetic studies on African buffalo (Syncerus caffer). Anim Genet 1999, 30:2 14-220.

16. Navani N, Jain PK, Gupta S, Sisodia BS, Kumar S: A set of cattle microsatellite DNA markers for genome analysis of riverine buffalo (Bubalus bubalis). Anim Genet 2002, 33: I49-154.

17. Kim KS, Min MS, An JH, Lee H: Cross-species amplification of Bovidae microsatellites and low diversity of the endangered Korean goral. J Hered 2004, 95:52 I-525.

18. Nguyen TT, Genini S, Menetrey F, Malek M, Vogeli P, Goe MR, Stranzinger G: Application of bovine microsatellite markers for 
genetic diversity analysis of Swiss yak (Poephagus grunniens). Anim Genet 2005, 36:484-489.

19. Moore SS, Evans D, Byrne K, Barker JS, Tan SG, Vankan D, Hetzel DJ: A set of polymorphic DNA microsatellites useful in swamp and river buffalo (Bubalus bubalis). Anim Genet 1995, 26:355-359.

20. Nguyen TT, Menetrey F, Genini S, Nguyen VL, Vogeli P, Nguyen BX, Stranzinger G: Application of bovine microsatellite markers on Saola (Pseudoryx nghetinhensis). J Anim Breed Genet 2005 122:195-198.

21. Edwards CJ, Gaillard C, Bradley DG, MacHugh DE: Y-specific microsatellite polymorphisms in a range of bovid species. Anim Genet 2000, $31: 127-130$

22. Ritz LR, Glowatzki-Mullis ML, MacHugh DE, Gaillard C: Phylogenetic analysis of the tribe Bovini using microsatellites. Anim Genet 2000, 3 I: 178-185.

23. Kemp SJ, Hishida O, Wambugu J, Rink A, Longeri ML, Ma RZ, Da Y, Lewin HA, Barendse W, Teale A): A panel of polymorphic bovine, ovine and caprine microsatellite markers. Anim Genet 1995, 26:299-306.

24. Hassanin A, Ropiquet A: Molecular phylogeny of the tribe Bovini (Bovidae, Bovinae) and the taxonomic status of the Kouprey, Bos sauveli Urbain 1937. Mol Phylogenet Evol 2004, 33:896-907.

25. Verkaar EL, Nijman IJ, Beeke M, Hanekamp E, Lenstra JA: Maternal and paternal lineages in cross-breeding bovine species. Has wisent a hybrid origin? Mol Biol Evol 2004, 2 I: I I65-I I70.

26. Buntjer JB, Otsen M, Nijman IJ, Kuiper MT, Lenstra JA: Phylogeny of bovine species based on AFLP fingerprinting. Heredity 2002 88:46-5I.

27. Ellegren H, Moore S, Robinson N, Byrne K, Ward W, Sheldon BC: Microsatellite evolution - a reciprocal study of repeat lengths at homologous loci in cattle and sheep. Mol Biol Evol 1997, | 4:854-860.

28. Hanotte O, Okomo M, Verjee Y, Rege E, Teale A: A polymorphic Y chromosome microsatellite locus in cattle. Anim Genet 1997 , 28:3|8-3|9.

29. Laird PW, Zijderveld A, Linders K, Rudnicki MA, Jaenisch R, Berns A: Simplified mammalian DNA isolation procedure. Nucleic Acids Res 1991, 19:4293.

30. Hassanin A, Pasquet E, Vigne JD: Molecular systematics of the subfamily Caprinae (Artiodactyla, Bovidae) as determined from cytochrome b sequences. J Mamm Evol 1998, 5:2 17-236.

31. Higuchi R: Rapid, efficient DNA extraction for PCR from cells or blood. Amplifications 1989, 2: I-3.

32. The Cattle Diversity Database [http://www.projects.ros lin.ac.uk/cdiv/accessdb.html]

33. The Cattle Genome Mapping Project database [http:// www.marc.usda.gov/genome/genome.html]

34. The BOVMAP database [http://locus.jouy.inra.fr/cgi-bin/bovmap/ intro2.pl]

35. The Microsatellite Toolkit [http://animalgenomics.ucd.ie/sde park/ms-toolkit/]

36. Nei M: Estimation of Average Heterozygosity and Genetic Distance from a Small Number of Individuals. Genetics 1978, 89:583-590.

37. Guo SW, Thompson EA: Performing the exact test of HardyWeinberg proportion for multiple alleles. Biometrics 1992, 48:36I-372.

38. Raymond M, Rousset F: GENEPOP: population genetics software for exact tests and ecumenicism. J Hered 1995, 86:248-249.

39. Botstein D, White RL, Skolnick M, Davis RW: Construction of a genetic linkage map in man using restriction fragment length polymorphisms. Am J Hum Genet 1980, 32:3 I4-33|.

40. Hishida O, Hanotte O, Verjee $Y$, Tanaka K, Namikawa T, Teale A Rege JEO: Crossspecies amplification and polymorphism of microsatellite loci in Asian bovidae. In Proceedings of the 8th AAAP Animal Science Congress: 13-18 October 1996; Tokyo, Japan Japanese Society of Zootechnical Science; 1996:354-355.
Publish with Bio Med Central and every scientist can read your work free of charge

"BioMed Central will be the most significant development for disseminating the results of biomedical research in our lifetime. "

Sir Paul Nurse, Cancer Research UK

Your research papers will be:

- available free of charge to the entire biomedical community

- peer reviewed and published immediately upon acceptance

- cited in PubMed and archived on PubMed Central

- yours - you keep the copyright
Biomedcentral 